\section{A List of Germplasm Releases from the University of Wisconsin Onion Breeding Program, 1957-1993}

\author{
I.L. Goldman ${ }^{1}$ \\ Department of Horticulture, University of Wisconsin-Madison, 1575 Linden \\ Drive, Madison, WI 53706
}

The onion (Allium cepa L.) breeding program at the Univ. of Wisconsin-Madison, initiated by W.H. Gabelman in 1949, was geared toward assessing the feasibility of $F_{1}$ hybrid onions. Many inbred lines and hybrids were released from the program over the past 39 years. Little description of these releases, other than that found in brief release notices, has been available for distribution to workers in the field of onion breeding and genetics. This report is an attempt to present a compilation of Gabelman's releases, including the year of release, line designation, salient features, and pedigree (Table 1). I hope that this information will be of use to onion breeders, seedsmen, and geneticists who use this germplasm in their research and development efforts. This report is presented as one in a series of reports describing Gabelman's vegetable

Received for publication 31 July 1995. Accepted for publication 28 Mar. 1996. The cost of publishing this paper was defrayed in part by the payment of page charges. Under postal regulations, this paper therefore must be hereby marked advertisement solely to indicate this fact.

${ }^{1}$ Assistant Professor of Horticulture. releases from the Univ. of Wisconsin (Goldman, 1996a, 1996b).

Early progress toward the development of $F_{1}$ hybrid onion cultivars required an understanding of male sterility, inbreeding potential, and seed production characteristics. The primary breeding objectives focused on disease resistance, storability, globe shape, improved color, scale thickness and retention, and combining ability. Gabelman's onion breeding program was heavily influenced by Henry Jones, director of the National Onion Breeding Program of the U.S. Dept. of Agriculture (USDA) in Beltsville, Md. Many of Gabelman's early releases contain germplasm developed by Jones.

The inbred lines and synthetic populations released from Gabelman's program have been used in the production of long-day onion hybrids throughout the world. Many of these inbreds have provided an important source of genes for disease resistance, storability, and scale quality in long-day onion hybrids. In particular, fusarium-resistant germplasm developed in this program paved the way for onion production in regions where this disease had resulted in severe yield loss.
The sterile lines developed by Gabelman incorporated the "S" cytoplasm first reported by Jones and Clarke from the USDA program (Jones and Clark, 1943). In addition to USDA germplasm resources, Gabelman relied heavily on three open-pollinated cultivars, 'Rochester Bronze' (a selection from 'Danvers Yellow Globe'), 'Subitch Yellow Globe', and 'Buckskin', for the derivation of early inbred lines. The cross 'Buckskin' x 'Rochester Bronze', obtained from Everett Horner of Waterford, Wis., was an important source of material during these early years.

The germplasm developed in Gabelman's program was typically released through the Univ. of Wisconsin and the Wisconsin State Agricultural Experiment Station. Inbred lines and hybrids developed before 1983 were released free of charge to the seed industry. Beginning in 1983, inbred lines were released to the seed industry on a royalty basis. Releases were permitted to be used free of charge in breeding programs, but if they served as parents of hybrids, a moderate royalty fee was charged. These fees are then returned to the Univ. of Wisconsin where they are used to support the continued development of the onion breeding program.

\section{Literature Cited}

Goldman, I.L. 1996a. A list of germplasm releases from the University of Wisconsin table beet breeding program, 1964-1992. HortScience 31:880-881.

Goldman, I.L. 1996b. A list of germplasm releases from the University of Wisconsin carrot breeding program, 1964-1994. HortScience 31:882883.

Jones, H.A. and A.E. Clarke. 1943. Inheritance of male sterility in the onion and the production of hybrid seed. Proc. Amer. Soc. Hort. Sci. 43:189-194.

Table 1. Year of release, name or number, description, and pedigree of onion germplsm released by W.H. Gabelman, 1957-93.

\begin{tabular}{|c|c|c|}
\hline $\begin{array}{l}\text { Year of } \\
\text { release }\end{array}$ & $\begin{array}{l}\text { Name or } \\
\text { no. }\end{array}$ & Description $^{\mathrm{z}}$ \\
\hline 1957 & $\mathrm{~W} 101 \mathrm{~A}^{\mathrm{y}}, \mathrm{W} 101 \mathrm{~B}^{\mathrm{x}}$ & $\begin{array}{l}\text { Inbred, moderately early maturity, firm, scales } \\
\text { golden bronze and heavy, tendency to double }\end{array}$ \\
\hline 1957 & Golden Beauty & $\begin{array}{l}\mathrm{F}_{1} \text { hybrid, high globe, well-rounded shoulders } \\
\text { and base, medium-sized neck, scales golden } \\
\text { yellow and soft }\end{array}$ \\
\hline 1962 & Nugget & $\mathrm{F}_{1}$ hybrid, firm, high globe, scales copper \\
\hline 1962 & Hickory & $\begin{array}{l}F_{1} \text { hybrid, round with small neck, firm scales, } \\
\text { good scale retention }\end{array}$ \\
\hline 1964 & W4A, W4B & $\begin{array}{l}\text { Inbred, ozone (tipburn) resistant, single-centered, } \\
\text { upright foliage, susceptible to pink root and } \\
\text { fusarium }\end{array}$ \\
\hline 1964 & Sunburst & $\begin{array}{l}\mathrm{F}_{1} \text { hybrid, globe shape, ozone (tipburn) resistant, } \\
\text { maturity similar to 'Epoch', yield similar to } \\
\text { Trapp's strain of 'Downing's Yellow Globe', } \\
\text { heavy scales }\end{array}$ \\
\hline 1966 & $\mathrm{~W} 52 \mathrm{C}^{\mathrm{w}}$ & $\begin{array}{l}\text { Inbred, round firm, carries male fertility } \\
\text { restorer alleles }(M s M s) \text {, good storage quality, } \\
\text { ozone (tipburn) resistant, upright foliage }\end{array}$ \\
\hline 1966 & $\mathrm{WD}^{\mathrm{v}} \mathrm{C}^{\mathrm{v}}$ & $\begin{array}{l}\text { Inbred, susceptible to pink root and fusarium, } \\
\text { general combining ability for yield }\end{array}$ \\
\hline 1967 & W202A, W202B & $\begin{array}{l}\text { Inbred, fusarium resistant, susceptible to } \\
\text { pink root }\end{array}$ \\
\hline 1967 & W205A, W205B & $\begin{array}{l}\text { Inbred, pink root resistant, moderate resistance } \\
\text { to fusarium }\end{array}$ \\
\hline
\end{tabular}

Pedigree
Derived from a Rochester Bronze bulb
obtained from Everett Horner, Waterford, Wis.
Parent bulb homozygous for $m s$ self-pollinated in
1950 ; selfed progeny grown in 1951
B2133 x B12132

Iowa 736 x W101

Iowa $163 \times \mathrm{W} 101$

Derived from B15-108 and B2267

W4A x W101B

Derived from 'Subitch Yellow Globe' obtained from Peter Subitch of Waukesha, Wis.

Derived from 'Brown Beauty'

Derived from 'Rochester Bronze'

Derived from inbred lines C72 and B2215 


\begin{tabular}{|c|c|c|c|}
\hline $\begin{array}{l}\text { Year of } \\
\text { release }\end{array}$ & $\begin{array}{l}\text { Name or } \\
\text { no. }\end{array}$ & Description $^{2}$ & Pedigree \\
\hline 1967 & W206C ${ }^{v}$ & $\begin{array}{l}\text { Inbred, pink root resistant, moderate resistance } \\
\text { to fusarium }\end{array}$ & Pink-root-resistant selection from B2190 \\
\hline 1967 & $\mathrm{~W} 207 \mathrm{C}^{\mathrm{v}}$ & $\begin{array}{l}\text { Inbred, pink root resistant, very resistant to } \\
\text { fusarium }\end{array}$ & Derived from inbred lines B2264 and B2215 \\
\hline 1972 & W404A, W404B & $\begin{array}{l}\text { Inbred, similar to W101 except with higher } \\
\text { level of resistance to fusarium and browner scales }\end{array}$ & $\begin{array}{l}\text { Sibling of W101 (a derivative of Rochester Bronze) } \\
\text { obtained from Everett Horner, Waterford, Wis. Also } \\
\text { called RBW101 }\end{array}$ \\
\hline 1972 & Fusario 12 & $F_{1}$ hybrid, fusarium resistant & W101 x W202 or the reciprocal \\
\hline 1972 & Fusario 24 & $\mathrm{~F}_{1}$ hybrid, fusarium resistant & W202 $\times$ W404 or the reciprocal \\
\hline 1972 & Fusario 245 & $\mathrm{~F}_{1}$ hybrid, fusarium resistant & Fusario 24 x W205 \\
\hline 1972 & Fusario 142 & $\mathrm{~F}_{1}$ hybrid, fusarium resistant & $(\mathrm{W} 101 \times \mathrm{W} 404) \times \mathrm{W} 202$ \\
\hline 1983 & W407A, W407B & $\begin{array}{l}\text { Inbred, susceptible to pink root and fusarium, } \\
\text { excellent seed parent and pollinator }\end{array}$ & Derived from the inbred lines W202 and W4 \\
\hline 1983 & W419A, W419B & $\begin{array}{l}\text { Inbred, resistant to pink root and fusarium, } \\
\text { some contorted seed stalks }\end{array}$ & Derived from the inbred lines W101 and W205 \\
\hline 1983 & W420A, W420B & $\begin{array}{l}\text { Inbred, resistant to pink root and fusarium, } \\
\text { some contorted seed stalks }\end{array}$ & $\begin{array}{l}\text { Derived from the inbred line W404 and BRB } \\
\text { (Buckskin Rochester Bronze) }\end{array}$ \\
\hline 1983 & W426A, W426B & $\begin{array}{l}\text { Inbred, susceptible to pink root and fusarium, } \\
\text { excellent general combining ability }\end{array}$ & Derived from the inbred lines W202 and W205 \\
\hline 1990 & W417A, W417B & Inbred, resistant to pink root and fusarium & Derived from W4 and BRB \\
\hline 1990 & W434A, W434B & $\begin{array}{l}\text { Inbred, intermediate pink root resistance and } \\
\text { high level of resistance to fusarium }\end{array}$ & $\begin{array}{l}\text { Derived from a half-sib population composed of in- } \\
\text { breds carrying resistance to several diseases }\end{array}$ \\
\hline 1990 & W435A, W435B & $\begin{array}{l}\text { Inbred, susceptible to pink root, very resistant } \\
\text { to fusarium }\end{array}$ & Same ancestry as W434 \\
\hline 1990 & W438A, W438B & $\begin{array}{l}\text { Inbred, moderate resistance to pink root, resistant } \\
\text { to fusarium }\end{array}$ & Same ancestry as W434 \\
\hline 1990 & W439A, W439B & $\begin{array}{l}\text { Inbred, pink root resistance and intermediate } \\
\text { resistance to fusarium }\end{array}$ & $\begin{array}{l}\text { Derived from the cross }(\mathrm{BRB} \times \mathrm{W} 404) \times \\
\text { Sapporo Ki }\end{array}$ \\
\hline 1990 & W440A, W440B & $\begin{array}{l}\text { Inbred, intermediate pink root resistance, high } \\
\text { level of resistance to fusarium }\end{array}$ & $\begin{array}{l}\text { Selected in } 1984 \text { from a synthetic population } \\
\text { constructed in } 1975 \text { (designated OMI). OMI was } \\
\text { synthesized from inbred lines with good seed pro- } \\
\text { duction capability }\end{array}$ \\
\hline 1990 & W441A, W441B & $\begin{array}{l}\text { Inbred, intermediate pink root resistance, } \\
\text { resistant to fusarium }\end{array}$ & Selected in 1984 from the synthetic OMI \\
\hline 1990 & $\mathrm{~W} 445 \mathrm{C}^{\mathrm{v}}$ & Inbred, susceptible to pink root and fusarium & $\begin{array}{l}\text { Derived from a } 1984 \text { selection from Sapporo } \\
\text { Ki x W202 }\end{array}$ \\
\hline 1990 & W446A, W446B & $\begin{array}{l}\text { Inbred, very resistant to pink root and } \\
\text { fusarium }\end{array}$ & Early maturing derivative of OMI \\
\hline 1990 & W447A, W447B & $\begin{array}{l}\text { Inbred, very resistant to pink root and } \\
\text { fusarium }\end{array}$ & Derivative of OMI \\
\hline 1990 & $\mathrm{~W} 449 \mathrm{C}^{\mathrm{v}}$ & $\begin{array}{l}\text { Inbred, intermediate pink root resistance, very } \\
\text { resistant to fusarium }\end{array}$ & Derived from Sapporo Ki x (BRB x W404) \\
\hline 1993 & W454A, W454B & $\begin{array}{l}\text { Inbred, white rot resistance, intermediate } \\
\text { tolerance to onion maggot, susceptible to pink } \\
\text { root and fusarium }\end{array}$ & Derived from W404 and PI2646540 \\
\hline 1993 & W455A, W455B & $\begin{array}{l}\text { Inbred, foliage blue-green, white rot resistant, } \\
\text { intermediate tolerance to onion maggot, } \\
\text { susceptible to pink root and fusarium }\end{array}$ & Derived from W404 and PI2646540 \\
\hline 1993 & W456A, W456B & $\begin{array}{l}\text { Inbred, white rot resistant, tolerance to onion } \\
\text { maggot, susceptible to pink root and fusarium }\end{array}$ & Derived from W404 and PI2646540 \\
\hline 1993 & W457A, W457B & $\begin{array}{l}\text { Inbred, white rot resistant, intermediate tolerance } \\
\text { to onion maggot, susceptible to pink root, } \\
\text { intermediate tolerance to fusarium }\end{array}$ & Derived from W404 and PI2646540 \\
\hline 1993 & W458A, W458B & $\begin{array}{l}\text { Inbred, white rot resistant, susceptible to pink } \\
\text { root, intermediate tolerance to fusarium }\end{array}$ & Derived from PI2646540 and W404 \\
\hline 1993 & W459A, W459B & $\begin{array}{l}\text { Inbred, white rot resistant, tolerance to onion } \\
\text { maggot, susceptible to pink root, intermediate } \\
\text { tolerance to fusarium }\end{array}$ & Derived from PI2646540 and W404 \\
\hline 1993 & W460A, W460B & $\begin{array}{l}\text { Inbred, white rot resistant, susceptible to pink } \\
\text { root and very resistant to fusarium }\end{array}$ & Derived from W404 and PI2646540 \\
\hline 1993 & W461A, W461B & $\begin{array}{l}\text { Inbred, white rot resistant, good tolerance to } \\
\text { onion maggot, moderate resistance to pink } \\
\text { root, intermediate tolerance to fusarium }\end{array}$ & Derived from PI264650 and W202 \\
\hline \multicolumn{4}{|c|}{$\begin{array}{l}\text { "Descriptions were compiled from field notebooks, release notices sent to agr } \\
\text { outer scales. Pink root is caused by the fungus Pyrenochaeta terrestris (Hans.) } \\
\text { injury. The onion maggot is Delia antiqua Meig. } \\
\text { "Genotype of "A" line for cytoplasm and nuclear-restorer locus is Smsms. } \\
{ }^{\mathrm{x}} \text { Genotype of "B" line for cytoplasm and nuclear-restorer locus is Nmsms. } \\
{ }^{\mathrm{w}} \text { Genotype of "C" line for cytoplasm and nuclear-restorer locus is NMSMS. } \\
{ }^{\mathrm{v}} \text { Genotype of "D" line for cytoplasm and nuclear-restorer locus is SMSMS. }\end{array}$} \\
\hline
\end{tabular}

